ROCZNIKI NAUK PRAWNYCH

Tom XXX, numer 2 - 2020

DOI: https://doi.org/10.18290/rnp20302-6

TOMASZ OCZKOWSKI

IGOR ZGOLIŃSKI

\title{
KLUCZOWE ASPEKTY ŚCIGANIA SPRAWCÓW OSZUSTW PODATKOWYCH
}

Prawo karne skarbowe jest w Polsce niewątpliwie odrębną gałęzią prawa karnego. W konsekwencji odpowiedzialność karna skarbowa jest odpowiedzialnością karną sensu largo, zaś w zakresie tworzenia norm materialnego oraz procesowego prawa karnego skarbowego pełne zastosowanie znajdują przepisy art. 42 ust. 1 i 2 Konstytucji RP. W przedmiocie pociągnięcia do odpowiedzialności oraz wymierzenia kary lub środka karnego za popełnienie deliktu karnego skarbowego winien co do zasady orzekać wyłącznie sąd. Forum tej czynności winno zaś stanowić pełne postępowanie, z gwarantowanym udziałem stron i kluczową rolą oskarżyciela publicznego oraz oskarżonego. Stąd też przesłanki pociągnięcia do odpowiedzialności karnej skarbowej, funkcje prawa karnego skarbowego oraz cele i zasady tego typu postępowań pozostają zbliżone do regulacji przewidzianych dla przestępstw powszechnych.

Niemniej jednak, zwłaszcza w kontekście części szczególnej Kodeksu karnego skarbowego [k.k.s.], obejmującej m.in. czyny przeciwko obowiązkom podatkowym, opis karalnego zachowania pozostaje poza treścią przepisów kodeksu. Jest to rozwiązanie oczywiste, albowiem karnoskarbowa ocena zachowania zawsze związana jest z naruszeniem przepisów prawa podatkowego.

Dr hab. Tomasz OczKowsKI - adiunkt, Katedra Prawa Karnego, Wydział Prawa i Administracji Uniwersytetu Mikołaja Kopernika w Toruniu, ul. Władysława Bojarskiego 3, 87-100 Toruń; e-mail: tomasz.oczkowski@umk.pl; ORCID: https://orcid.org/0000-0002-1479-3801

Prof. KPSW, dr hab. IGOR ZGOLIŃSKI - Prorektor do spraw Nauki, Katedra Prawa Karnego, Wydział Nauk Prawnych, Społecznych i Humanistycznych Kujawsko-Pomorskiej Szkoły Wyższej w Bydgoszczy, ul. Toruńska 55-57, 85-023 Bydgoszcz; e-mail: i.zgolinski@kpsw.edu.pl; ORCID: https://orcid.org/0000-0002-5097-6170 
W tym pryzmacie bezprawie podatkowe jest pierwotne, a bezprawie karne skarbowe ma charakter wtórny ${ }^{1}$. Problem jednak w tym, że dynamiczna rzeczywistość nie zamierza się stosować do założeń leżących u podstaw kodeksowej polityki kryminalnej. Od kilkunastu lat można zauważyć istotny wzrost przestępczości godzącej w efektywność podatkową. Należy zgodzić się ze stanowiskiem, że najbardziej karygodną grupę przestępstw podatkowych, polegającą na uchylaniu się od obowiązku zapłaty podatku (oszustwa podatkowe), możemy podzielić na właściwe i niewłaściwe 2 . Oczywiście, granica między nimi jest trudna do sprecyzowania, ale druga grupa oszustw to zachowania jednoznacznie bezprawne, gdzie zamiarem sprawców jest $\mathrm{z}$ góry uzyskanie korzyści majątkowych kosztem interesów fiskalnych ${ }^{3}$. Innymi słowy, powinności podatnika są tu drugorzędne, gdyż istota tych zachowań wiąże się z wywodzeniem skutków podatkowo istotnych opierających się na fikcyjnych zdarzeniach, którym towarzyszą nierzetelne dokumenty oraz podmioty firmujące rzeczywistą aktywność innych podmiotów. Taki mechanizm słusznie określa się zorganizowaną przestępczością wpisaną w podatkowy kontekst, której celem jest dokonywanie uszczupleń w mieniu Skarbu Państwa ${ }^{4}$. Na tym tle oszustwa właściwe jawią się jako wszystkie te przypadki, gdzie nie można w sposób jednoznaczny wywieść (a następnie często także dowodowo ustalić), że jedynym i wiodącym celem dla sprawców było dokonanie uszczuplenia należności publicznoprawnej. Etiologia tego stanu rzeczy bywa rozmaita (np. czyny te zostały popełnione podczas, niejako „,przy okazji” legalnie prowadzonej działalności, mającej znacznie szerszy zakres, i nie można stwierdzić, że zostały popełnione w sposób zorganizowany).

Przestępczość zorganizowana jest natomiast zjawiskiem nie tylko rozpoznawanym w Polsce, lecz zataczającym coraz szersze kręgi. Niewątpliwie demokratyzacja życia politycznego, swoboda przemieszczenia się i inne aspekty

\footnotetext{
${ }^{1}$ L. WILK, Szczególne cechy odpowiedzialności za przestępstwa $i$ wykroczenia skarbowe, Katowice: Wydawnictwo Uniwersytetu Śląskiego 2006, s. 148-150; T. OcZKOWSKI, Komentarz do art. 53 k.k.s., [w:] Kodeks karny skarbowy. Komentarz, red. I. Zgoliński, Warszawa: Wolters Kluwer 2018, s. 273.

${ }^{2}$ D. KoRCZYŃSKI, Funkcja fiskalna prawa karnego skarbowego, [w:] Węzlowe zagadnienia prawa karnego skarbowego, red. D. Korczyński, P. Jóźwiak, P. Herbowski, Warszawa: Wydawnictwo C.H. Beck 2017, s. 100; por. także I. ZGOLIŃSKI, Wystawienie lub postugiwanie się nierzetelnym dokumentem podatkowym, „Prokuratura i Prawo” 2012, nr 3, s. 162.

${ }^{3}$ Tamże.

${ }^{4}$ P. KolODZIEJSKI, Skuteczność ścigania przestępczości skarbowej a zmiany systemowe, „Prokuratura i Prawo” 2015, nr 3, s. 88; J. DuŻy, Zorganizowana przestępczość podatkowa w Polsce. Zwalczanie przestępnego nadużycia mechanizmów podatków VAT i akcyzowego, Warszawa: Wolters Kluwer 2013, s. 15.
} 
wolności politycznej oraz ekonomicznej, jakie nastąpiły w wyniku przemiany ustrojowej, sprzyjały tej szczególnej postaci przestępczości. Pierwsze lata po 1989 r. potwierdziły, że przestępczość zorganizowana dopuszcza się na szeroką skalę przestępstw powszechnych, takich jak kradzieże, przestępstwa rozbójnicze, porwania dla okupu, handel ludźmi i wszelkie inne aspekty nielegalnej, a wręcz przestępczej aktywności, które przynoszą duże korzyści majątkowe (były to przede wszystkim obszary działalności związane z narkotykami, fałszywymi środkami płatniczymi, prostytucją, oszustwa komputerowe). W tej postaci przestępczości nie mamy do czynienia z kwestią ochrony interesów fiskalnych Państwa, a korzyści majątkowe uzyskiwane z przestępstw powszechnych co do zasady powinny być objęte przepadkiem na rzecz Skarbu Państwa, jako jedną z konsekwencji sądowego orzeczenia skazującego. Korzyści tego rodzaju nie mogą być przedmiotem opodatkowania podatkiem dochodowym lub nawet podatkiem obrotowym (np. $z$ tytułu obrotu fałszywymi środkami pieniężnymi), gdyż państwo nie może czerpać dochodów w postaci podatków z aktywności obywateli o charakterze przestępczym ${ }^{5}$. Zauważalna w ostatnich latach ewolucja tej przestępczości, przenikającej do codziennego życia gospodarczego, dała jednak asumpt do modyfikacji przepisów zwiększających efektywność systemu podatkowego. Z tego powodu zadać trzeba pytanie, czy przyjęty model ścigania i zwalczania przestępczości podatkowej jest skuteczny w kontekście nowego kształtu tej przestępczości.

\section{ZMIANY W SFERZE KOMPETENCJI RZECZOWYCH FINANSOWYCH ORGANÓW POSTĘPOWANIA PRZYGOTOWAWCZEGO}

Począwszy od 2016 r. do dnia dzisiejszego ustawodawca pozostaje bardzo aktywny na polu zmian legislacyjnych, które w wielkim skrócie można uznać jako działania podejmowane w celu uszczelnienia systemu podatkowego, zarówno w zakresie podatków pośrednich (podatek akcyzowy oraz podatek od towarów i usług), jak i w zakresie podatku dochodowego. Równolegle do istotnych zmian $\mathrm{w}$ sferze prawa podatkowego ustawodawca dokonał także zmian w Kodeksie karnym i Kodeksie karnym skarbowym, które dotyczyły

\footnotetext{
${ }^{5}$ Zob. uzasadnienie uchwały SN z dnia 19 lipca 1973 r., OSNKW 1973, nr 9, poz. 104; postanowienie SN z dnia 15 stycznia 2015 r. III KK 313/14, LEX 164818; wyrok SA w Lublinie z dnia 9 sierpnia 2012 r., II AKa 111/12, LEX nr 1237245; zob. także T. OcZKOWsKI, Glosa do postanowienia $S N$ z 22.11.2011 r., IV KK 270/2011, LEX nr 1095847, „Przegląd Orzecznictwa Podatkowego" 2013, nr 6, s. 521-523.
} 
zwiększenia efektywności reakcji karnej na poszerzającą się skalę niewłaściwych oszustw podatkowych.

Najważniejszą z interesujących nas zmian w sferze kodeksu karnego jest nowela tej ustawy z dnia 10 lutego 2017 r. (Dz.U. 2017.244), która weszła w życie z dniem 1 marca 2017 r. Niewątpliwie przez ten zabieg legislacyjny ustawodawca jednoznacznie przesądził, że zjawisko wystawiania „pustych” faktur, jako narzędzie dla celów korzyści fiskalnych lub wręcz wyłudzania mienia przez pozorowanie zdarzeń gospodarczych i oszukańcze żądanie zwrotu „nadwyżki” naliczonego podatku od towarów i usług, jest typowym przestępstwem powszechnym. Przestępstwa powszechne zaś są ścigane przez Prokuraturę i Policję, a nie przez wyspecjalizowany aparat fiskalny w postaci finansowych organów postępowania przygotowawczego.

W przypadku Kodeksu karnego skarbowego relewantne zmiany obejmowały zarówno przepisy prawa materialnego, jak i procesowego. Pierwsze z nich wiązały się z zaostrzeniem kar i modyfikacją przepisów dotyczących tzw. nierzetelnych rachunków, faktur, paragonów i innych dowodów w obrocie gospodarczym. Dokonano ich na podstawie ustawy z dnia 1 grudnia $2016 \mathrm{r}$. o zmianie ustawy o podatku od towarów i usług oraz niektórych innych ustaw (Dz.U. poz. 2024), która weszła w życie z dniem 1 stycznia 2017 r. W ramach tego aktu prawnego m.in. zmodyfikowano brzmienie art. 62 k.k.s., penalizującego wystawianie lub posługiwanie się nierzetelnymi rachunkami lub fakturami. Co więcej, do okoliczności obligujących do nadzwyczajnego obostrzenie kary za przestępstwa karne skarbowe zaliczono fakt skazania sprawcy za przestępstwo skarbowe z art. $62 \S 2$ k.k.s. (obejmujące wystawienie nierzetelnej faktury lub rachunku lub posługiwanie się tego rodzaju dokumentem) w sytuacji, w której kwota podatku z tego rodzaju faktur jest co najmniej dużej wartości, czyli odpowiada co najmniej równowartości pięćsetkrotności minimalnego wynagrodzenia z dnia czynu (vide: art. $53 \S 13$ k.k.s.). Jednocześnie do art. $38 \S 2$ k.k.s. dodano pkt 3 i tym samym najbardziej rygorystyczne zasady obostrzenia kary w k.k.s. objęły także czyn z art. $62 \S 2$ k.k.s., o ile przedmiotem osądzonego czynu jest faktura lub faktury opiewające na kwotę podatku od towarów i usług w kwocie odpowiadającej co najmniej tysiąckrotności minimalnego wynagrodzenia. Nie ulega wątpliwości, że obie zmiany w prawie materialnym potwierdziły, że choć k.k.s. formalnie nadal ma pozostawać instrumentem ścigania sprawców naruszeń obowiązków podatkowych, to ustawodawca jednoznacznie dąży do tego, aby najbardziej karygodne w jego ocenie zachowania, powiązane z oszustwami podatkowymi, były ścigane jako „typowe" przestępstwa kryminalne. 
Druga grupa zmian legislacyjnych miała bardzo szeroki zakres i wiązała się z gruntowną reformą organów podatkowych, celnych i organów kontroli skarbowej, co znalazło odzwierciedlenie w ustawie z dnia 16 listopada 2016 r. o Krajowej Administracji Skarbowej (Dz.U. poz. 1947 - dalej: ustawa KAS), która weszła w życie z dniem 1 marca 2017 r. Ustawa KAS nie zmieniła modelu postępowania karnego skarbowego, gdzie szczególną pozycję procesową zarówno w postępowaniu przygotowawczym, jak i w postępowaniu sądowym zajmowały dotychczas organy podatkowe i celne, jako tzw. finansowe organy postępowania przygotowawczego. Ustawa ta ukształtowała jednak zupełnie nową strukturę organów podatkowych i celnych, co w konsekwencji wymusiło także zmiany następcze $\mathrm{w}$ treści k.k.s.. W wielkim skrócie wskazać należy, że jako finansowe organy postępowania przygotowawcze od dnia 1 marca 2017 r., obok dotychczasowego naczelnika urzędu skarbowego, pojawił się naczelnik urzędu celno-skarbowego oraz Szef KAS. Istotne jest również to, że organy te zajmują szczególną pozycję ${ }^{6}$. Pierwszy uzyskał bowiem upoważnienie do wykrywania i ścigania wszelkich poważniejszych przestępstw skarbowych, w tym oszustw podatkowych, a drugi, tj. Szef KAS, ma prawo ścigać każdy z czynów ujętych w k.k.s.. Trafnie więc wskazuje S. Dudziak, że jako jeden z celów ustawy KAS było swoiste wyspecjalizowanie naczelnika urzędu skarbowego oraz naczelnika urzędu celno-skarbowego. Pierwszy z organów zasadniczo ma zajmować się poborem podatków od podatników, kontrolą ich rozliczeń podatkowych oraz egzekucją należnych podatków. Naczelnik urzędu celno-skarbowego ma natomiast zajmować się nadzorem nad podatnikami podatku akcyzowego i działalnością hazardową, a nadto został uprawniony do prowadzenia szerokiego zakresu czynności kontrolnych. Pozostawiono mu również wszystkie kompetencje organu celnego. Ale, co istotne, to ten organ uzyskał „policyjne” kompetencje operacyjno-rozpoznawcze do wykrywania i ścigania przestępczości zorganizowanej wpisanej w kontekst podatkowy i celny. Rację ma S. Dudziak również twierdząc, że zakres kompetencji rzeczowych naczelnika urzędu celno-skarbowego uprawnia do przyjęcia stanowiska, że ten organ KAS stał się podstawowym „zbrojnym ramieniem” aparatu skarbowego ${ }^{7}$. Tym bardziej że do wyłącznej kompetencji rzeczowej naczelnika urzędu celno-skarbowego jako „nowego” finansowego organu postępowania

\footnotetext{
${ }^{6}$ Zob. R. OLSZEWSKI, Wybrane aspekty ostatnich nowelizacji Kodeksu karnego skarbowego ze szczególnym uwzględnieniem zmian ustrojowych organów administracji skarbowej, „Przegląd Podatkowy" 2017, nr 9, s. 11-13.

7 S. DUDZIAK, Krajowa Administracja Skarbowa a postępowanie karne skarbowe, „Prokuratura i Prawo" 2017, nr 4, s. 97.
} 
przygotowawczego w rozumieniu k.k.s., przekazano poważniejsze typy przestępstw podatkowych, tj. czynów stypizowanych w art. $54 \S 1$, art. $55 \S 1$, art. 56 $\S 1$, art. 63-68, art. $69 \S 1,3$ i 4, art. 69a-70, art. 73-73a, art. 75a-75c, art. 76 $\S 1$, art. $77 \S 1$, art. $78 \S 1$, art. 85-95, art. $96 \S 1$, art. 97-106k, art. 107-110b i art. $111 \S 1$ k.k.s. ${ }^{8}$

$\mathrm{W}$ interesującym nas aspekcie istotne jednak pozostaje, że doszło do znaczącego poszerzenia kompetencji rzeczowych jednego z organów KAS. Zgodnie $\mathrm{z}$ art. $33 \mathrm{a}$ ust. 1 oraz art. 2 ust. 1 pkt 15 ustawy KAS, naczelnik urzędu celno-skarbowego jest także uprawniony do ścigania przestępstw powszechnych, takich jak udział $w$ grupie lub związku przestępczym (art. 258 k.k.), czyny przeciwko wiarygodności dokumentów, w tym przestępstwa fakturowe (art. 270-270a k.k., art. 271-271a k.k., art. 273 k.k. i art. 277a k.k.), oszustwo (art. $286 \S 1$ k.k.) oraz pranie brudnych pieniędzy (art. 299 k.k.) ${ }^{9}$. Warunkiem uzyskania takiego uprawnienia jest to aby ujawnienie w/w przestępstw nastąpiło podczas czynności służbowych funkcjonariuszy lub pracowników KAS, w szczególności przy kontroli celno-skarbowej. To rozwiązanie teoretycznie zapobiegać miało problemowi dwutorowości działań dochodzeniowo-śledczych. W sferze przestępstw powszechnych ściganie tego rodzaju przestępstw należy przecież do kompetencji prokuratora, przy wsparciu Policji, podczas gdy czyny karne skarbowe zasadniczo są ścigane przez aparat skarbowy. Rola prokuratora w sprawach karnych skarbowym jest istotna, lecz - nie wchodząc w szerokie rozważania - zasadniczo jest to funkcja nadzoru nad czynnościami podejmowanymi przez finansowe organy postępowania przygotowawczego. W mniejszym zakresie rola ta sprowadzała się do samodzielnego prowadzenia tego typu postępowań, a na ogół było to i tak wynikiem informacji powziętej od organów administracji skarbowej. Nie zmienia to jednak faktu, iż nie można uznać, aby legislator pozostawał w pełni konsekwentny. Na tym polu

\footnotetext{
${ }^{8}$ Tamże, s. 101-103. Autor trafnie wskazuje na praktyczny problem: ściganie oszustw podatkowych o niższej kwocie uszczuplenia pozostawiono we właściwości rzeczowej naczelnika urzędu skarbowego, co w sytuacji ustalenia w toku postępowania, że oceniany czyn spowodował uszczuplenie podatkowe wyczerpujące znamiona np. oszustwa podatkowego z art. $54 \S 1$ k.k., będzie skutkować koniecznością przekazania prowadzonej sprawy do właściwego miejscowo naczelnika urzędu celno-skarbowego.

${ }^{9}$ Por. J. ZAWIEJSKA-RATAJ, A. PodSIAdŁy, Rozpoznawania, wykrywanie, ściganie i zwalczanie czynów zabronionych, zapobieganie im i ściganie ich sprawców przez organy Krajowej Administracji Skarbowej, „Przegląd Podatkowy” 2017, nr 10, s. 39-40. Zob. także P. KoŁodzIEJSKI, Skuteczność ścigania przestępczości skarbowej a zmiany systemowe, „Prokuratura i Prawo” 2015, nr 3, s. 88-89, który takie rozwiązania formułował jako jeden z postulatów wskazując, że np. czyny przeciwko wiarygodności dokumentów oraz pranie brudnych pieniędzy są czynami towarzyszącymi niewłaściwym oszustwom podatkowym.
} 
rozważań, z racji ram niniejszego opracowania, ograniczymy się jednak wyłącznie do jednej, zasadniczej, kwestii, jakkolwiek w dotychczasowym modelu ścigania, rozpoznawanie i wykrywanie przejawów przestępczości zorganizowanej i przestępczości gospodarczej należało do zadań Policji i Prokuratury. Taki model nie był żadnym zaskoczeniem - przestępczość zorganizowana nie kojarzy się bowiem z legalną i jawną aktywnością ekonomiczną, z którą wiążą się zdarzenia skutkujące obowiązkiem zapłaty podatku. Ustawa KAS formalnie przekazała naczelnikom urzędów celno-skarbowych prawo do ścigania przestępstwa prania brudnych pieniędzy, tj. czynu z art. $299 \S 1$ k.k. Prima facie jest to rozwiązanie racjonalne, gdyż w takiej konfiguracji mamy do czynienia z pewnego rodzaju „systemem naczyń połączonych”, gdzie przestępstwo karne skarbowe jest przestępstwem bazowym dla przestępstwa prania brudnych pieniędzy. Bliższa analiza weryfikuje jednak to zapatrywanie. Dotychczasowe doświadczania związane z wykrywaniem i ściganiem „właściwych" oszustw podatkowych wskazują na istotne znaczenie procedur notyfikacyjnych, wprowadzonych w ramach przeciwdziałania zjawisku prania brudnych pieniędzy. Trafnie przy tym podkreśla się w doktrynie, że prawne regulacje dotyczące zwalczania zjawiska legalizacji przestępczych korzyści (poszerzone następnie także o zwalczania zjawiska finansowania terroryzmu) obejmują trzy odrębne płaszczyzny. Zalicza się do nich: 1) kryminalizację prania brudnych pieniędzy, 2) objęcie niektórych podmiotów, w szczególności instytucji finansowych, obowiązkami aktywnego udziału w ujawnianiu podejrzanych transakcji i przepływów finansowych, ze szczególnych akcentem na gromadzenie danych o podejrzanych przepływach finansowych i ich uczestnikach wraz z obowiązkiem notyfikacji podejrzanych zdarzeń wyspecjalizowanym organom publicznym, 3) ustanowienie wyspecjalizowanych organów publicznych, uprawnionych do uzyskiwania i gromadzenia informacji o podejrzanych przepływach finansowych i ich uczestnikach wraz z nałożeniem na nie obowiązku inicjowania postępowań karnych ${ }^{10}$. Tego rodzaju rozwiązania zostały wprowadzone także w Polsce. Aktualnie w tej materii obowiązuje ustawa z dnia 1 marca 2018 r. o przeciwdziałaniu praniu pieniędzy

${ }^{10}$ Zob. J. BOJARSKI, Przestępstwa gospodarcze związane z działalnością banków, Toruń: TNOiK 2001, s. 70; T. OCZKOWSKI, Przepadek i pranie brudnych pieniędzy jako środki mające na celu pozbawienie korzyści majatkowych uzyskanych z przestępstw, [w:] Węzłowe problemy prawa karnego, kryminologii i polityki kryminalnej. Księga pamiatkowa ofiarowana Profesorowi Andrzejowi Markowi, red. V. Konarska-Wrzosek, J. Lachowski, J. Wójcikiewicz, Warszawa: Wolters Kluwer Polska 2010, s. 413-414. 
oraz finansowaniu terroryzmu (t.j. Dz.U. 2019, poz. 1115), zaś pranie brudnych pieniędzy jest także kryminalizowane w art. $299 \S 1$ k.k. Nie wchodząc w złożone kwestie dogmatyczne, uznać należy, że legalizacja korzyści osiąganych $\mathrm{z}$ oszustw podatkowych często jest przedmiotem przestępstwa prania brudnych pieniędzy ${ }^{11}$. Dla prowadzonych rozważań istotne jest to, że przyjęty w Polsce trójpłaszczyznowy model zwalczania przejawów prania brudnych pieniędzy był i jest istotnym elementem wszczynania postępowań karnych przeciwko sprawcom niewłaściwych oszustw podatkowych. W piśmiennictwie J. Duży i P. Kołodziejski wskazują, że w 2013 r. nastąpił drastyczny wzrost wartości tzw. transakcji podejrzanych zgłaszanych przez Generalnego Inspektora Informacji Finansowej (dalej: GIIF) jako podejrzenie popełnienia przestępstwa prania brudnych pieniędzy. Była to kwota trzykrotnie wyższa w stosunku do wartości zgłoszonych w 2012 r., a wynosiła łącznie 15,25 mld złotych. Większość z tej kwoty dotyczyła przestępstw bazowych związanych $\mathrm{z}$ wyłudzeniem zwrotu podatku od towarów i usług lub z uszczupleniem tego podatku $^{12}$. Podkreśla się także, że zakres informacji przekazywanych przez GIIF bardzo często implikuje pokusę odmowy wszczęcia postępowania karnego, z uwagi na brak danych pozwalających na określenie, z jakiego czynu przesłane środki pochodzą. Zawiadomienia dokonywane przez GIIF praktycznie zawsze wiążą się z koniecznością podjęcia wielu czynności procesowych, których realizacja dopiero może doprowadzić do ustalenia, z jakiego przestępstwa bazowego prane środki pochodzą ${ }^{13}$. Podkreślenia wymaga, że przyjęty

${ }^{11}$ J. DuŻY, P. KoŁODZIEJSKI, Pranie pieniędzy zwiąanych z uszczupleniami podatkowymi, [w:] Wybrane aspekty nowelizacji prawa karnego. Zagadnienia penalizacji prania pieniędzy $w$ świetle projektowanych nowelizacji. Kognicja sadu $w$ sprawach wpadkowych $w$ postepowaniu karnym, red. M. Kolendowska-Matejczuk, K. Szwarc, Warszawa: Biuro Rzecznika Praw Obywatelskich 2015, s. 29, tak też SA w Katowicach, w wyroku z dnia 27 lipca 2016 r., II AKa 219/16, Lex nr 2107572, zob. jednak G. KĘDZIERSKA, Nielegalny handel towarami akcyzowymi, [w:] Nielegalne rynki. Geneza, skala zjawiska oraz możliwości przeciwdziałania, red. W. Pływaczewski, P. Chlebowicz, Olsztyn: Katedra Kryminologii i Polityki Kryminalnej, Wydział Prawa i Administracji, Uniwersytet Warmińsko-Mazurski 2012, s. 312, która wskazuje, że w przypadku uchylania się od zapłaty podatku kwota uszczuplonego podatku nie musi być częścią ceny, a więc przepływy finansowe formalnie nie obejmują kwoty nie uiszczonego podatku (w szczególności jest to widoczne w obszarze obrotu wyrobami tytoniowymi bez akcyzy, gdzie „podziemna” cena transakcyjna jest niższa od ceny w legalnym obrocie).

${ }^{12}$ J. DuŻY, P. KoŁODZIEJSKI, Pranie pieniędzy zwiazanych z uszczupleniami podatkowymi, s. 30.

13 Tamże, s. 32-33; zob. także J. DuŻY, Ściganie przestepczości zorganizowanej w zakresie obrotu złomem i paliwami, „Prokuratura i Prawo” 2010, nr 7-8, s. 73-75, który podkreśla, że zawiadomienia GIIF, o ile dotyczą jeszcze aktywnych operacji, skutkują także zakończeniem ujawnionego procederu i powodują wypracowanie nowego schematu aktywności, co także wpływa na niską efektywność w pozbawianiu korzyści majątkowych z tego rodzaju czynów. 
model inicjowania przez GIIF postępowań karnych w sprawach prania brudnych pieniędzy zupełnie nie uwzględnia zmian wynikających z ustawy KAS. GIIF bowiem składa informacje mające na celu inicjowanie spraw karnych wyłącznie do prokuratora (zob. art. 86 ust. 8 oraz art. 87 ust. 3 ustawy o przeciwdziałaniu praniu pieniędzy oraz finansowaniu terroryzmu). Innymi słowy, skoro do ujawnienia podejrzenia dokonania czynów z art. $299 \S 1$ k.k. dochodzi przez działanie GIIF, to nie jest na ogół możliwe ujawnienie tego rodzaju czynu w ramach czynności służbowych aparatu KAS. Nie od rzeczy będzie zauważyć, że mająca tu zastosowanie ustawa wskazuje wyłącznie prokuratora jako podmiot uprawniony do otrzymania zawiadomienia o podejrzeniu dokonania przestępstwa prania brudnych pieniędzy. Ustawodawca nie dokonał, jak dotąd, w tym zakresie stosownych modyfikacji, wynikających z przeobrażeń aparatu fiskalnego. Dodać należy, że przedmiot prania brudnych pieniędzy podlega $\mathrm{w}$ całości odrębnemu przepadkowi na podstawie art. $299 \S 7$ k.k. ${ }^{14}$, co czyni całkowicie uboczną kwestię istnienia zaległości podatkowych i możliwość efektywnego pozyskania należnych wpływów podatkowych. Stąd też praktyczne aspekty związane ze ściganiem niewłaściwych oszustw podatkowych powodują, że poszerzenie kompetencji organów KAS w tej sferze niewiele zmieni. Nadal ściganie tego rodzaju czynów będzie pozostawać głównie w gestii prokuratora i Policji.

\section{WYMIAROWA DECYZJA PODATKOWA JAKO PREJUDYKAT W SPRAWACH KARNOSKARBOWYCH}

W kontekście analizy systemowego podejścia do problemu efektywnego zwalczania przestępczości zorganizowanej wpisanej w kontekst podatkowy, zasadne jest poruszenie jeszcze jednego zagadnienia. Wszelkie oceny karne skarbowe w zakresie oszustw podatkowych są możliwe dopiero wtedy, gdy doszło do naruszenia przepisów prawa podatkowego. Stąd też jest oczywiste, że konieczną cechą typowych oszustw podatkowych jest wystąpienie zaległości podatkowej (lub tzw. narażenie należności publicznoprawnej na uszczuplenie). Poza dyskusją jest bowiem, że przy typowych oszustwach podatkowych z art. 54 i art. 56 k.k.s. kwota uszczuplenia podatkowego należy do znamion każdego z tych czynów. W sferze zarówno praktycznej, jak i teoretycznej ważnym za-

\footnotetext{
${ }^{14}$ Tak J. RAglewSKI, Przepadek $w$ ramach regulacji przestępstwa prania brudnych pieniędzy - uwagi de lege lata i de lege ferenda, [w:] Wybrane aspekty nowelizacji prawa karnego, s. 42.
} 
gadnieniem staje się samodzielność sądu karnego w ustaleniu wysokości zaległości podatkowej. Nie bez znaczenia jest tu okoliczność, że niewłaściwe oszustwa podatkowe dotyczą przede wszystkim tzw. podatków pośrednich, czyli podatku akcyzowego oraz podatku od towarów i usług. Te zaś należą do podatków, które powstają z mocy prawa, tj. obowiązek ich zapłaty wiąże się $\mathrm{z}$ wystąpieniem określonego $\mathrm{w}$ ustawie podatkowej zdarzenia (np. dostawa towaru). Dodatkowo, to na podatniku spoczywa tzw. instrumentalny obowiązek podatkowy, polegający na obowiązku złożenia w terminie deklaracji podatkowej. Innymi słowy, powstanie obowiązku podatkowego w podatku akcyzowym lub w podatku od towarów i usług skutkuje dwoma obowiązkami podatnika, to jest obowiązkiem zapłaty należnego podatku oraz obowiązkiem złożenia deklaracji podatkowej zgodnej ze stanem rzeczywistym. Przepisy podatkowe stanowią przy tym jednoznacznie, że w tych podatkach przyjmuje się domniemanie zgodności treści deklaracji podatkowej ze stanem rzeczywistym (por. art. $21 \S 1$ pkt 1, art. $21 \S 2$ i 3 ustawy z dnia 29 sierpnia 1997 r. Ordynacja podatkowa, t. j. Dz.U. 2019, poz. 900 - dalej: O.p.). Domniemanie to może uchylić wyłącznie decyzja podatkowa określająca wysokość zaległości podatkowej z podatkowego okresu rozliczeniowego, za który złożono deklarację podatkową. Prawne znaczenie złożenia deklaracji podatkowej trafnie określono w wyroku NSA z dnia 14 marca 2014 r. ${ }^{15}$, gdzie wskazano, że przy obowiązku zapłaty podatku opartego na zasadzie samoobliczenia, a więc tych, które powstają z dniem zaistnienia zdarzenia, wysokość zobowiązania podatkowego co do zasady przyjmuje się w wysokości wynikającej ze złożonej deklaracji. We wskazanym judykacie słusznie zaakcentowano, że „dopiero jeżeli w postępowaniu podatkowym organ podatkowy stwierdzi, że podatnik, mimo ciążącego na nim obowiązku, nie zapłacił w całości lub w części podatku, nie złożył deklaracji albo że wysokość zobowiązania podatkowego jest inna niż wykazana $\mathrm{w}$ deklaracji, organ podatkowy wydaje decyzję, w której określa wysokość zobowiązania podatkowego (art. 21 § 3 O.p.)".

Powyższy stan prawny powoduje więc, że z pewnością nie ma tu zastosowania art. $8 \S 2$ k.p.k., który wyłącza samodzielność jurysdykcyjną sądu karnego przy innych orzeczeniach sądowych o charakterze konstytutywnym ${ }^{16}$. Decyzje podatkowe przy podatkach opartych na zasadzie samoobliczenia nie

\footnotetext{
${ }^{15}$ I FSK 275/13, Lex nr 1487637.

${ }^{16}$ T. DUDEK, Zawieszenie postępowania karnego skarbowego ze względu na prejudykat, „Prokuratura i Prawo" 2012, nr 11, s. 86-87, przy czym pomijamy tu kwestię związania sądu karnego konstytutywnymi rozstrzygnięciami organów administracji, w tym administracji skarbowej, bo i tak chodzi tu o deklaratoryjne rozstrzygnięcia organów skarbowych.
} 
tworzą zobowiązania podatkowego, a tylko określają poprawną jego wysokość we wcześniejszych okresach podatkowych. Mają zatem charakter deklaratywny. Uwzględniając powyższe, w sposób nieodzowny pojawia się jednak pytanie o dopuszczalność możliwości podważania treści deklaracji podatkowej w sprawach karnych skarbowych. W świetle art. $8 \S 1$ k.p.k. (stosowanym za pośrednictwem art. $113 \S 1$ k.k.s.) sąd karny rozstrzyga samodzielnie zagadnienia faktyczne i prawne sprawy oraz nie jest związany rozstrzygnięciami innego sądu lub organu. Uregulowanie to ma oczywiście zastosowanie również w postępowaniu karnym skarbowym. Zdaniem T. Dudka sąd karny nie ma samodzielności w ustaleniu wysokości zaległości podatkowej przy oszustwach podatkowych. Autor przyjął, że brak odpowiedniej decyzji organu podatkowego, nawet deklaratoryjnej, powoduje, iż taki obowiązek świadczenia przez podatnika nie powstaje. Jest to o tyle nieprecyzyjne, że obowiązek ten powstaje przecież z mocy prawa. Nie zmienia to jednak faktu, że przepisy prawa podatkowego przewidują prawne domniemanie zgodności treści deklaracji podatkowej ze stanem rzeczywistym. Domniemanie to może być obalone wyłącznie przez decyzję właściwego organu podatkowego o ustaleniu istnienia zaległości podatkowej. Takie zaś rozumowanie winno prowadzić do wniosku, że w sprawach, w których podatnik złożył nieprawdziwą w treści deklarację podatkową, dla ocen karnych skarbowych pod kątem oszustwa podatkowego niezbędne jest wydanie decyzji podatkowej o określeniu zaległości podatkowej. Sąd karny nie powinien mieć wszakże kompetencji rzeczowej do podważenia prawnego domniemania zgodności treści deklaracji podatkowej ze stanem rzeczywistym $^{17}$. Z drugiej natomiast strony w postępowaniu karnym obowiązuje zasada prawdy materialnej i nakaz wszechstronnego ustalenia stanu faktycznego, na którym winno być oparte orzeczenie merytoryczne. Zakres samodzielności orzekania sądu karnego determinowany jest zaś przedmiotem danego postępowania oraz pozostałymi kwestiami implikującymi rozstrzygnięcie w tym przedmiocie. Te elementy, rozpatrywane łącznie, wyznaczają zakres kognicji

${ }^{17} \mathrm{Za}$ samodzielnością jurysdykcyjną sądu karnego przy ustaleniu wysokości zaległości podatkowej opowiadają się m.in.: G. ŁABUDA, Zawieszenie postępowania karnego skarbowego ze względu na prejudykat, „Prokuratura i Prawo” 2011, nr 3, s. 82; J. DużY, Kompetencja sądu karnego do ustalenia kwoty uszczuplonego podatku, „Prokuratura i Prawo” 2014, nr 1, s.115; I. ZGOLIŃSKI, Komentarz do art. 56 k.k.s., [w:] Kodeks karny skarbowy. Komentarz, s. 380-382. Natomiast jeszcze dalej idzie w swym stanowisku M. Charkiewicz, który wyłącza prawo sądu karnego do ustalenia zaległości podatkowej także w przypadku braku deklaracji podatkowej, zob. M. Charkiewicz, Samodzielność jurysdykcyjna sądu karnego na gruncie art. 54 i 56 ustawy Kodeks karny skarbowy - rzeczywistość znana i nieznana, „Prawo i Podatki” 2012, nr 12, s. 20. 
sądu karnego ${ }^{18}$. Na ogół aprobowana jest koncepcja związania sądu karnego decyzją administracyjną, jako przesłanką odpowiedzialności karnej wynikającą ze znamion typu czynu zabronionego. Negowane jest z kolei stanowisko, że decyzje organów skarbowych ustalające istnienie lub nieistnienie zobowiązania podatkowego oraz określające wysokość podatku wiążą sądy karne. W tej perspektywie w postępowaniach o przestępstwa skarbowe i wykroczenia skarbowe zasada samodzielności jurysdykcyjnej sądu karnego obowiązuje, stosownie do art. 113 k.k.s., i nie podlega ani osłabieniu, ani innym wyjątkom niż te, które zostały określone w treści przepisu art. $8 \S 2$ k.p.k. ${ }^{19}$ Sąd karny opierając się na takim stanie prawnym, jest więc formalnie legitymowany do tego, by badać kwestię istnienia zobowiązania podatkowego oraz wysokość podatku określonego decyzją organów administracyjnych. Wiążą go bowiem nie tyle przepisy sensu largo prawa podatkowego, ile przepisy prawa karnego procesowego, prawa karnego skarbowego oraz prawa karnego powszechnego. Odmienne stanowisko w tej kwestii ogranicza zaś rolę sądu i statuuje jako organ określający li tylko konsekwencje karne skarbowe w świetle wiążących ustaleń organów administracyjnych. W określonych sytuacjach procesowych, wcale nierzadkich w praktyce, sąd może być natomiast wręcz obowiązany do samodzielnego ustalenia tej kwestii, jeśli istnienie zobowiązania podatkowego lub wysokość podatku należnego, określonego w drodze decyzji administracyjnej, budzą istotne wątpliwości, które mogą oddziaływać tak na egzystencję, jak i na sam zakres odpowiedzialności karnej skarbowej.

\section{WNIOSKI}

Powyższe rozważania, z natury rzeczy obejmujące tylko fragment złożonego problemu reakcji karnej na oszustwa podatkowe, są niewątpliwie podstawą do weryfikacji zasadności utrzymania aktualnego kształtu rozwiązań prawnokarnych w tym względzie. Warto zastanowić się nad postulatem i rozpocząć dyskusję o tym, czy sankcje za właściwe oszustwa podatkowe nie mogłyby stać się sankcjami administracyjnymi, a najpoważniejsza grupa czynów z kategorii oszustw podatkowych, w tym poszerzająca się grupa czynów na przedpolu oszustw podatkowych, byłaby kryminalizowana wyłącznie jako przestępstwa powszechne. Zwalczanie przestępczości zorganizowanej było

${ }^{18}$ P. HofMAŃSKI, Samodzielność jurysdykcyjna sądu karnego, Katowice: Uniwersytet Śląski 1988, s. 17-18.

${ }^{19}$ Wyrok SN z dnia 29 października 2015r., IV KK 185/15, LEX nr 1929133. 
i z pewnością pozostanie domeną prokuratora i Policji. Przy tego typu przestępczości efektywność funkcji fiskalnej k.k.s. jest iluzoryczna, zaś karygodność przestępstwa niezwykle duża. Stąd też nie jest zaskoczeniem, zarówno $\mathrm{w}$ aspekcie praktycznym, jak i w aspekcie legislacyjnym, że wyłudzenia zwrotu podatku oraz posługiwanie się „pustymi” fakturami są uznawane za typowe przestępstwa kryminalne. Po wtóre, w sytuacji, w której podatnik jest podmiotem realnym, a nie narzędziem grupy osób, wystarczające na ogół są sankcje administracyjne oraz dodatkowe następstwa nakładane w związku z nienależnym rozliczeniem podatkowym. W stosunku do podatników i osób ich reprezentujących nie prowadziłoby się wówczas postępowań karnych skarbowych, które dla tych podmiotów są często wysoce piętnujące i stanowią nieadekwatną, nadmierną reakcję państwową ${ }^{20}$. Przy okazji zniwelowaniu uległaby większość kwestii spornych w interpretacji przepisów, wynikłych na styku prawa podatkowego z postępowaniem karnym. W sytuacji, w której w wielu wypadkach można mieć różnego rodzaju wątpliwości co do wystąpienia znamion strony podmiotowej, bezwzględne następstwa administracyjne kierowane do podatnika (a nie do jego reprezentantów) byłyby zapewne bardziej adekwatne i pragmatyczne, a co najważniejsze - szybsze i skuteczniejsze.

\section{BIBLIOGRAFIA}

\section{ŹRÓDŁA PRAWA}

Konstytucja RP, Dz.U. z 1997 r., Nr 78, poz. 483.

Ustawa z dnia 29 sierpnia 1997 r. - Ordynacja podatkowa, t.j. Dz.U. z 2019 r., poz. 900.

Ustawa z dnia 1 grudnia 2016 r. o zmianie ustawy o podatku od towarów i usług oraz niektórych innych ustaw, Dz.U. poz. 2024.

Ustawa z dnia 16 listopada 2016 r. o Krajowej Administracji Skarbowej, Dz.U. poz. 1947.

Ustawa z dnia 10 lutego 2017 r. o zmianie ustawy - Kodeks karny oraz niektórych innych ustaw, Dz.U.2017.244.

Ustawa z dnia 1 marca 2018 r. o przeciwdziałaniu praniu pieniędzy oraz finansowaniu terroryzmu, t.j. Dz.U. z 2019 r., poz. 1115.

ORZECZNICTWO

Uchwała SN z dnia 19 lipca 1973 r., OSNKW 1973, nr 9, poz. 104.

Wyrok SA w Lublinie z dnia 9 sierpnia 2012 r., II AKa 111/12, LEX nr 1237245.

\footnotetext{
${ }^{20}$ Por. I. SEPIOŁO-JANKOWSKA, Optymalny model odpowiedzialności prawnej za czyny karne skarbowe, Warszawa: Wydawnictwo C.H. Beck 2016, s. 229.
} 
Wyrok NSA z dnia 14 marca 2014 r. I FSK 275/13, LEX nr 1487637.

Postanowienie SN z dnia 15 stycznia 2015 r., III KK 313/14, LEX nr 164818.

Wyrok SN z dnia 29 października 2015r., IV KK 185/15, LEX nr 1929133.

Wyrok SA w Katowicach z dnia 27 lipca 2016 r., II AKa 219/16, Lex nr 2107572.

\section{LITERATURA}

BOJARSKI Janusz: Przestępstwa gospodarcze związane z działalnością banków, Toruń: TNOiK 2001.

ChARKIEwICZ Mariusz: Samodzielność jurysdykcyjna sądu karnego na gruncie art. 54 i 56 ustawy Kodeks karny skarbowy - rzeczywistość znana i nieznana, „Prawo i Podatki” 2012, nr 12, s. 18-24.

DuDEK Tomasz: Zawieszenie postępowania karnego skarbowego ze względu na prejudykat, „Prokuratura i Prawo" 2012, nr 11, s. 84-111.

DUDZIAK Sławomir: Krajowa Administracja Skarbowa a postępowanie karne skarbowe, „Prokuratura i Prawo" 2017, nr 4, s. 95-107.

DuŻy Jerzy: Kompetencja sądu karnego do ustalenia kwoty uszczuplonego podatku, „Prokuratura i Prawo" 2014, nr 1, s. 106-120.

DuŻY Jerzy, KoŁodZIEJSKI Paweł: Pranie pieniędzy związanych z uszczupleniami podatkowymi, [w:] Wybrane aspekty nowelizacji prawa karnego. Zagadnienia penalizacji prania pieniędzy w świetle projektowanych nowelizacji. Kognicja sądu w sprawach wpadkowych w postępowaniu karnym, red. Marta Kolendowska-Matejczuk, Karolina Szwarc, Warszawa: Biuro Rzecznika Praw Obywatelskich 2015, s. 29-39.

DuŻY Jerzy: Ściganie przestępczości zorganizowanej w zakresie obrotu złomem i paliwami, „Prokuratura i Prawo" 2010, nr 7-8, s. 71-86.

DuŻY Jerzy: Zorganizowana przestępczość podatkowa w Polsce. Zwalczanie przestępnego nadużycia mechanizmów podatków VAT i akcyzowego, Warszawa: Wolters Kluwer Polska 2013.

HOFMAŃSKI Piotr: Samodzielność jurysdykcyjna sądu karnego, Katowice: Uniwersytet Śląski 1988.

KĘDZIERSKA Grażyna: Nielegalny handel towarami akcyzowymi, [w:] Nielegalne rynki. Geneza, skala zjawiska oraz możliwości przeciwdziałania, red. Wiesław Pływaczewski, Piotr Chlebowicz, Olsztyn: Katedra Kryminologii i Polityki Kryminalnej, Wydział Prawa i Administracji, Uniwersytet Warmińsko-Mazurski 2012, s. 304-321.

KoŁODZIEJSKI Paweł: Skuteczność ścigania przestępczości skarbowej a zmiany systemowe, „Prokuratura i Prawo" 2015, nr 3, s. 86-105.

KORCZYŃSKI Dawid: Funkcja fiskalna prawa karnego skarbowego, [w:] Węzłowe zagadnienia prawa karnego skarbowego, red. Dawid Korczyński, Piotr Jóźwiak, Piotr Herbowski, Warszawa: Wydawnictwo C.H. Beck 2017, s. 99-118.

ŁABUDA Grzegorz: Zawieszenie postępowania karnego skarbowego ze względu na prejudykat, „Prokuratura i Prawo" 2011, nr 3, s. 77-83.

OCZKOwSKI Tomasz: Glosa do postanowienia SN z 22.11.2011 r., IV KK 270/2011, LEX nr 1095847, „Przegląd Orzecznictwa Podatkowego” 2013, nr 6, s. 518-523.

OCZKOwSKI Tomasz: Komentarz do art. 53 k.k.s., [w:] Kodeks karny skarbowy. Komentarz, red. Igor Zgoliński, Warszawa: Wolters Kluwer 2018, s. 272-346.

OCZKOWSKI Tomasz: Przepadek i pranie brudnych pieniędzy jako środki mające na celu pozbawienie korzyści majątkowych uzyskanych z przestępstw, [w:] Węzłowe problemy prawa karnego, kryminologii i polityki kryminalnej. Księga pamiątkowa ofiarowana Profesorowi Andrzejowi 
Markowi, red. Violetta Konarska-Wrzosek, Jerzy Lachowski, Józef Wójcikiewicz, Warszawa: Wolters Kluwer Polska 2010, s. 407-430.

OLSZEWSKI Radosław: Wybrane aspekty ostatnich nowelizacji Kodeksu karnego skarbowego ze szczególnym uwzględnieniem zmian ustrojowych organów administracji skarbowej, „Przegląd Podatkowy" 2017, nr 9, s. 11-16.

RAGLEWSKI Janusz: Przepadek w ramach regulacji przestępstwa prania brudnych pieniędzy - uwagi de lege lata $i$ de lege ferenda, [w:] Wybrane aspekty nowelizacji prawa karnego. Zagadnienia penalizacji prania pieniędzy w świetle projektowanych nowelizacji. Kognicja sądu w sprawach wpadkowych w postępowaniu karnym, red. Marta Kolendowska-Matejczuk, Karolina Szwarc, Warszawa: Biuro Rzecznika Praw Obywatelskich 2015, s. 40-47.

SEPIOŁO-JANKOWSKA Iwona: Optymalny model odpowiedzialności prawnej za czyny karne skarbowe, Warszawa: Wydawnictwo C.H. Beck 2016.

WILK Leszek: Szczególne cechy odpowiedzialności za przestępstwa i wykroczenia skarbowe, Katowice: Wydawnictwo Uniwersytetu Śląskiego 2006.

ZAWIEJSKA-RATAJ Joanna, PoDSIADŁY Artur: Rozpoznawania, wykrywanie, ściganie i zwalczanie czynów zabronionych, zapobieganie im i ściganie ich sprawców przez organy Krajowej Administracji Skarbowej, „Przegląd Podatkowy” 2017, nr 10, s. 37-42.

ZGOLIŃSKI Igor: Komentarz do art. 56 k.k.s., [w:] Kodeks karny skarbowy. Komentarz, red. Igor Zgoliński, Warszawa: Wolters Kluwer 2018, s. 380-382.

ZGOLIŃSKI Igor: Wystawienie lub posługiwanie się nierzetelnym dokumentem podatkowym, „Prokuratura i Prawo" 2012, nr 3, s. 156-168.

\section{KLUCZOWE ASPEKTY ŚCIGANIA SPRAWCÓW OSZUSTW PODATKOWYCH}

\section{Streszczenie}

W treści artykułu autorzy przedstawiają obecny kształt i mankamenty przepisów związanych z pociągnięciem do odpowiedzialności karnej skarbowej sprawców oszustw podatkowych. Wskazują, że istniejące rozwiązania są często niepraktyczne, nie przystają do otoczenia społeczno-gospodarczego. Dla zobrazowania tego zagadnienia koncentrują swe rozważania wokół nowo przyznanych kompetencji rzeczowych finansowych organów postępowania przygotowawczego oraz wymiarowej decyzji podatkowej, postrzeganej jako prejudykat w sprawach karnoskarbowych. Konkluzją artykułu jest propozycja, aby dokonać weryfikacji zasadności dalszego utrzymywania dotychczasowego kształtu rozwiązań prawnokarnych oraz rozważyć możliwość przesunięcia odpowiedzialności tzw. właściwych oszustw podatkowych na płaszczyznę odpowiedzialności administracyjnej. Odpowiedzialności karnej skarbowej w tym świetle podlegaliby wyłącznie sprawcy najpoważniejszych przestępstw, dokonywanych zasadniczo na przedpolu oszustw podatkowych. W tym bowiem przypadku kryminalne zabarwienie czynu posiada bardzo wyraźną przewagę nad jego zabarwieniem fiskalnym, w ramach szeroko rozumianej społecznej szkodliwości tego rodzaju przestępstw. To niewątpliwie winno determinować odpowiedzialność karną.

Słowa kluczowe: odpowiedzialność karna skarbowa; prawo karne skarbowe jako odrębna gałąź prawa karnego; nowy kształt przestępczości podatkowej; dwutorowość reakcji karnej; samodzielność jurysdykcyjna sądu w postępowaniach karnych skarbowych 


\title{
KEY ASPECTS OF PROSECUTING TAX FRAUD PERPETRATORS
}

\begin{abstract}
S u m m ary
In the content of the article, the authors present the current shape and shortcomings of the provisions related to bringing tax perpetrators to tax liability. They indicate that existing solutions are often impractical and do not fit into the socio-economic environment. To illustrate this issue, they focus their considerations on newly granted competences of the financial authorities of preparatory proceedings and dimensional tax decision, seen as a prejudication ruling in fiscal penal cases. The conclusion of the article is a proposal to verify the legitimacy of further maintaining the current shape of criminal law solutions and to consider the possibility of shifting the responsibility of the so-called "proper tax frauds" on the plane of administrative liability. In this view, fiscal criminal liability would only apply to the perpetrators of the most serious crimes committed generally in the foreground of tax fraud. In this case, the criminal tone of the act, has a very clear advantage over its fiscal tone, as part of the broadly understood social harmfulness of such crimes. This undoubtedly should determine criminal liability.
\end{abstract}

Key words: fiscal criminal liability; fiscal law as a separate branch of criminal law; new shape of a tax crime; the "double-track" criminal response; jurisdictional independence of the court in fiscal penal proceedings 